\title{
COMPRESSIVE AND DIAMETRAL TENSILE STRENGTH OF GLASS IONOMER CEMENTS
}

\author{
RESISTÊNCIA À COMPRESSÃO E À TRAÇÃO DIAMETRAL DE \\ CIMENTOS DE IONÔMERO DE VIDRO
}

\author{
Eduardo BRESCIANI ${ }^{1}$, Terezinha de Jesus Esteves BARATA ${ }^{1}$, Ticiane Cestari FAGUNDES ${ }^{2}$, \\ Akimi ADACHI ${ }^{3}$, Marina Martins TERRIN ${ }^{3}$, Maria Fidela de Lima NAVARRO ${ }^{4}$
}

\begin{abstract}
1- DDS, MSc, PhD, Graduate Student, Department of Operative Dentistry, Bauru Dental School, University of São Paulo, Brazil.
2- DDS, MSc, Graduate Student, Department of Operative Dentistry, Bauru Dental School, University of São Paulo, Brazil.

3- Undergraduate Student of Bauru Dental School, University of São Paulo, Brazil.

4- Associate Professor of Operative Dentistry, Dean of Bauru Dental School, University of São Paulo, Brazil.

Corresponding address: Profa. Dra. Maria Fidela de Lima Navarro - Department of Operative Dentistry, Bauru Dental School University of São Paulo - Alameda Dr. Octávio Pinheiro Brisolla 9-75, CEP: 17.012-101 - Bauru - São Paulo- Brazil

Phone: 55-14-3224-7688 - Fax: 5514 3223-4679 - E-mail: mflnavar@usp.br
\end{abstract}

Received: July 28, 2004 - Returned for modification: August 27, 2004 - Accepted: September 28, 2004

\begin{abstract}
$T_{\text {he aim of this study was to compare, in different periods of time, the compressive and diametral tensile strength of a traditional high }}$ viscous glass ionomer cement: Fuji IX (GC Corporation), with two new Brazilian GIC’s: Vitro-Molar (DFL) and Bioglass R (Biodinamica), all indicated for the Atraumatic Restorative Treatment (ART) technique. Fifteen disk specimens (6.0mm diameter x 3.0mm height) for the diametral tensile strength (DTS) test and fifteen cylindrical specimens (6.0 mm diameter $\mathrm{x} 12.0 \mathrm{~mm}$ height) for the compressive strength (CS) test were made of each GIC. Specimens were stored in deionized water at $37^{\circ} \mathrm{C}$ and $100 \%$ of humidity in a stove until testing. Five specimens of each GIC were submitted to CS and DTS test in each period, namely 1 hour, 24 hours and 7 days. The specimens were tested in a testing machine (Emic) at a crosshead speed of $1.0 \mathrm{~mm} / \mathrm{min}$ for CS and $0.5 \mathrm{~mm} / \mathrm{min}$ for the DTS test until failure occurred. The data were submitted to two-way ANOVA and Tukey tests $(\alpha=0.05)$. The mean CS values ranged from 42.03 to $155.47 \mathrm{MPa}$ and means DTS from 5.54 to 13.72 $\mathrm{MPa}$, with test periods from $1 \mathrm{~h}$ to 7 days. The CS and DTS tests showed no statistically significant difference between Fuji IX and Vitro Molar, except for CS test at 1-hour period. Bioglass R had lowest mean value for CS of the cements tested. In DTS test Bioglass R presented no statistically significant differences when compared with all others tested GICs at 1-hour period and Bioglass R presented no difference at 24-hour and 7-day periods when compared to Vitro-Molar. Further studies to investigate other physical properties such as fracture toughness and wear resistance, as well as chemical composition and biocompatibility, are now needed to better understand the properties of these new Brazilian GIC’s.

Uniterms: Glass ionomer cements, mechanical properties; Atraumatic Restorative Treatments; Compressive strength; Diametral tensile strength.
\end{abstract}

\footnotetext{
RESUMO

C

omparou-se a Resistência à Compressão (RC) e à Tração Diametral (TD) de um cimento de ionômero de vidro de alta viscosidade [Fuji IX (GC Corporation)] e de dois novos cimentos Brasileiros [Vitro Molar (DFL) e Bioglass R (Biodinamica)], recentemente lançados no mercado, ambos indicados para o Tratamento Restaurador Atraumático (ART), em diferentes períodos de tempo. Foram confeccionados quinze corpos-de-prova com 6,0 mm de diâmetro x 3,0 mm de altura para o teste de TD e quinze com 6,0 mm de diâmetro e 12,0 mm de altura para o teste de RC, para cada ionômero a ser testado. Os corpos-de-prova foram armazenados em recipientes plásticos, com água deionizada, e mantidos em estufa a $37^{\circ} \mathrm{C}$ e $100 \%$ de umidade, até a realização dos testes. Cinco corpos-de-prova de cada material foram submetidos aos testes de TD e RC em cada período de tempo: 1-hora, 24-horas e 7-dias, em uma máquina de testes universal (EMIC - DL 500) a uma velocidade de $1,0 \mathrm{~mm} / \mathrm{min}$ para RC e $0,5 \mathrm{~mm} / \mathrm{min}$ para TD. Os dados obtidos foram submetidos aos testes ANOVA a dois critérios e Tukey (á=0,05). Os valores médios de RC e TD variaram de 42,03 a 155.47 MPa e de 5,54 a 13,72 MPa, respectivamente para os períodos analisados. O Fuji IX e o Vitro Molar não apresentaram diferenças em relação aos testes de RC e TD, exceto para RC no período de 1-hora. O Bioglass R apresentou os menores valores de RC dos cimentos testados. Na TD o Bioglass R não apresentou diferença em relação aos outros cimentos testados no período de 1-hora e não foi diferente do Vitro-Molar nos períodos de 24-horas e 7-dias. Mais estudos são necessários para avaliar outras propriedades mecânicas desses novos cimentos de ionômero de vidro brasileiros, tais como: tenacidade e desgaste, bem como composição química e biocompatibilidade

Unitermos: Cimentos de ionômero de vidro, propriedades mecânicas; Tratamento Restaurador Atraumático; Resistência à compressão; Resistência à tração diametral.
} 


\section{INTRODUCTION}

Conventional Glass Ionomer Cements (GICs) were introduced to the dental professional in 1971 by Wilson \& Kent $^{22}$ as materials consisting of a base-usually an ionleachable, calcium-aluminum-fluorosilicate glass powder-that is combined with polyacrylic acid or its copolymers ${ }^{16}$. These cements possess certain unique properties that make them useful as restorative and adhesive materials, including adhesion to moist tooth structure and base metals, anticariogenic properties due to release of fluoride, thermal compatibility with tooth enamel because of low coefficient of thermal expansion similar to those of tooth structure, biocompatibility and low cytotoxicity $^{7,16}$. The limitations include the brittleness and poor fracture toughness of the materials $s^{7,15}$.

Due to their considerable advantages and improvement, GICs have been widely indicated in the Atraumatic Restorative Treatment (ART) technique ${ }^{9,12}$. The ART is an approach of caries removal using only hand instruments, and restoring the cavity and sealing any associated fissures and pits with an adhesive restorative material, such as the currently used GICs. The approach combines a preventive component with a restorative procedure, and has the potential to be minimally invasive and maximally preserve the tooth structure ${ }^{9,12}$.

But, due to inadequate physical properties of the glass ionomer materials to resist occlusal forces ${ }^{2}$, efforts to improve several aspects of this treatment have been made, involving different kinds of self-cured GICs, such as inclusion of more reactive polyacids (e.g. copolymers of acrylic and maleic acid), by pretreatment of the glass surfaces and with modified glass compositions ${ }^{11,23}$. Besides all the developments in the hybrid systems, there has been a potential development in the field of conventional acid/glass systems with the development of high viscosity GICs, as Fuji IX (GC Corporation) ${ }^{8,10,11}$. The particular ways of improving conventional GICs consisted mainly of optimizing the concentration and molecular weight of the polyacid as well as the particle size distribution of the glass ${ }^{11}$.

The compressive and diametral tensile strengths are common tests to determine the mechanical properties of glass ionomers $4,6,9,10,19,21,23,24$.
As Brazilian GIC indicated for ART technique are commercially available and no previous study was performed with these materials, the aim of this study was to compare the compressive and diametral tensile strengths of a traditional Glass-Ionomer Cement(GIC): Fuji IX-GC Corporation, with two Brazilian marketed GICs: Vitro-Molar (DFL) and Bioglass R (Biodinamica), all indicated for Atraumatic Restorative Treatment (ART) technique.

\section{MATERIALAND METHODS}

The three chemically-cured glass-ionomer cements (GICs) tested in this study are listed on Table 1.

In accordance with ADA specifications $66^{1}$ five specimens were prepared for each material and for each of three periods of time: 1 hour, 24 hours and 7 days, to evaluate compressive (CS) and diametral tensile strengths (DTS). The cylinder dimensions were $6.0 \mathrm{~mm}$ diameter $\mathrm{x} 12.0 \mathrm{~mm}$ height for the CS test and $6.0 \mathrm{~mm}$ diameter $\mathrm{x}$ 3.0mm height for the DTS test.

The powder/liquid ratios were used according to the manufacturers' instructions for all materials. The material necessary to make each specimen was weighted in a precision balance and mixed with a plastic spatula (GC Corporation, Tokyo, Japan) on impermeable paper.

The specimens were made at room temperature of $23 \pm 2^{\circ} \mathrm{C}$ and relative air humidity of $50 \pm 10 \%$, as recommended by ADA specification ${ }^{1}$. After mixing, the materials were inserted with a Centrix syringe (Centrix, Shelton, USA) into metallic matrices, which were previously coated with a thin layer of petroleum jelly (Sidepal, Guarulhos, Brazil). The insertion was done slowly to adapt the material into the matrix and avoid bubble formation. The matrices were slightly overfilled with the GIC; a polyester strip (Proben, Catanduva, Brazil) covered with a thin layer of petroleum jelly was placed on the material and a coverslip was placed on top of it. Hand pressure was then applied for 20 seconds while excess material was extruded from the top of the matrices for DTS test. For CS test matrices were compressed in a device. Two minutes after the start of the mix, the matrices were placed in an oven at $37 \pm 1^{\circ} \mathrm{C}$ and $95 \pm 5 \%$ relative humidity,

TABLE 1- Materials, manufacturers, GIC classification, powder:liquid (P:L) ratio, and batch numbers

\begin{tabular}{|c|c|c|c|c|}
\hline Materials & Manufacturers & Classification & P:L ratio & Batch numbers- valid \\
\hline \multirow[t]{2}{*}{ Bioglass R } & Biodinamica & Restorative & $3.0: 1.0$ & 157/04-03/2006 \\
\hline & Ibiporã, Brazil & Conventional & & \\
\hline \multirow[t]{3}{*}{ Fuji IX } & GC Corporation & Restorative & $3.6: 1.0$ & $0309051-09 / 2006$ \\
\hline & Tokyo, Japan & Conventional & & \\
\hline & & High Viscositiy & & \\
\hline \multirow[t]{3}{*}{ Vitro Molar } & DFL & Restorative & $3.0: 1.0$ & 020144-11/2006 \\
\hline & Rio de Janeiro & Conventional & & \\
\hline & Brazil & & & \\
\hline
\end{tabular}


for 15 minutes. Then, the specimens were ejected from the matrices and the excess material was removed with a carver and petroleum jelly was applied to protect the GIC during the initial setting reaction. The specimens were afterward stored in $6 \mathrm{~mL}$ of deionized water at $37 \pm 1^{\circ} \mathrm{C}$. Tests were made in an Emic Universal Testing Machine (Emic- DL 5000/10000, São José dos Pinhais-PR-Brazil) at a crosshead speed of $1.0 \mathrm{~mm} / \mathrm{min}$ for $\mathrm{CS}$ and $0.5 \mathrm{~mm} / \mathrm{min}$ for the DTS test.

For the DTS test, the specimens were compressed diametrically introducing tensile stress in the material in the plane of the force application by the test (Figure 1). This was calculated by the formula: $2 \mathrm{P} /=\pi \mathrm{DT}$, where: $\mathrm{P}=$ load applied; $\mathrm{D}=$ diameter of the cylinder, $\mathrm{T}=$ thickness of the cylinder, $\pi=$ (constant) 3,14. DTS values [ $\left.\mathrm{kgf} / \mathrm{cm}^{2}\right]$ were converted into $\mathrm{MPa}$ as follows: DTS[MPa]=DTS[Kgf/cm2] x 0.09807. For the CS test, the specimens were placed in vertical position, with force

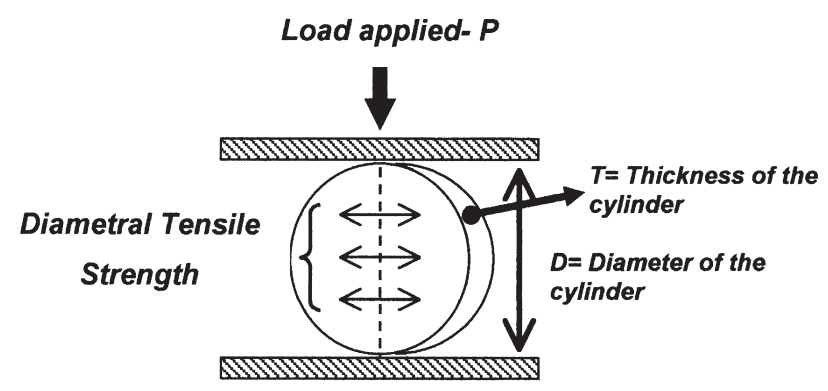

FIGURE 1- Schematic illustration of Diametral Tensile Strength adapted from Darvell ${ }^{7}, 2000$.

How diametral tensile is envisaged ideally tension acting smoothly over the entire diameter, peak at the center ${ }^{7}$.

\section{Compressive Strength}

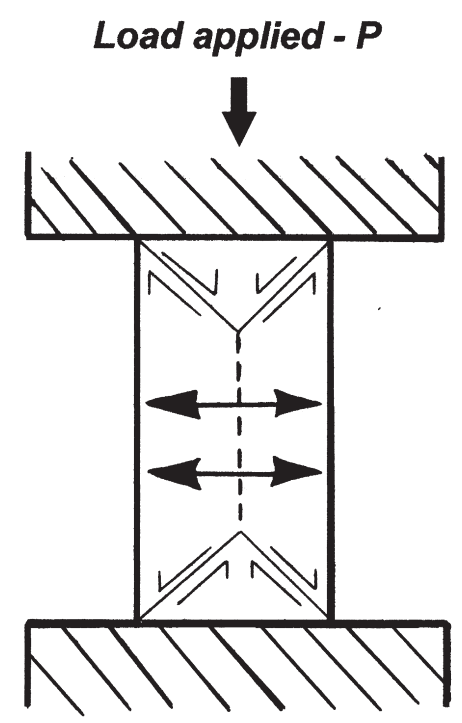

FIGURE 2- Schematic illustration of Compressive Strength adapted from Darvell ${ }^{7}, 2000$.

The stress and causes of failure in a cylindrical specimen loaded axially are no different from those in the diametral case except that the pattern is radially symetrical ${ }^{7}$. incident on the long axis (Figure 2). The CS was calculated by the following formula: $\mathrm{P} / \pi \mathrm{r}^{2}$. Where: $\mathrm{P}=$ load at fracture, $\mathrm{r}=$ the radius of sample cylinder, and $\pi=$ (constant) 3.14. CS values [kgf/ $\left.\mathrm{cm}^{2}\right]$ were converted into MPa as follows: CS $[\mathrm{MPa}]=\mathrm{CS}\left[\mathrm{Kgf} / \mathrm{cm}^{2}\right] \times 0.09807$.

The data were submitted to two-way ANOVA (GICs and time) and Tukey-Kramer test for individual comparison with a 0.05 level of significance.

\section{RESULTS}

The CS and DTS test results for the GICs are shown in Tables 2 and 3.

\section{Compressive Strength}

- All GICs tested presented a significant increase in CS between the 1-hour and 7-day periods $(\mathrm{p}<0.001)$.

- Bioglass R and Vitro Molar and Fuji IX presented statistically significant difference between 1-hour and 24-hour periods. There were no differences between the 24-hour and 7day periods.

- There were statistically significant differences between all GICs at the 1-hour period.

- Bioglass R and Fuji IX showed statistically significant difference at the 24-hour and 7-day periods.

- Vitro Molar and Fuji IX showed no statistically significant difference at the 24-hour and 7-day periods.

- Bioglass R presented lower strengths than the others GICs included in this study at the 3 tested periods.

\section{Diametral Tensile Strength}

- Two-way analysis showed significant differences among materials, where Bioglass R $<$ Vitro Molar $<$ Fuji IX ( $p=0.00)$ and among periods of evaluation, where 1 hour $<1$ day $<1$ week $(p=0.00)$.

- Bioglass R and Vitro Molar presented no statistically significant differences between the 3 analyzed periods ( 1 hour, 24 hours and 7 days)

- Fuji IX presented lower DTS at 1-hour when compared to 24-hour and 7-day periods.

-At 1 hour there were no differences among the materials.

- At 24 hours and 7 days, Bioglass R presented statistically significant lower DTS than Fuji IX

- At 24 hours and 7 days, Vitro Molar presented no statistical difference when compared to Bioglass R and Fuji IX.

\section{DISCUSSION}

The resistance to fracture within a restorative material is specified by a fracture stress, which is often referred to as the strength of the material ${ }^{24}$. Two mechanical strength tests (Compressive and Diametral Tensile) were used in this study. The compressive strength (CS) is an important property in restorative materials, particularly in the process of mastication. 
This test is more suitable to compare brittle materials, which show relatively low result when subject to tension ${ }^{7,17}$. To test compressive strength of a material, two axial sets of force are applied to a sample in an opposite direction, in order to approximate the molecular structure of the material ${ }^{20}$.

The diametral tensile strength (DTS) is a critical requirement, because many clinical failures are due to tensile stress ${ }^{15}$. As it is not possible to measure the tensile strength of brittle materials like Glass Ionomer Cements (GICs) directly, the British Standards Institution adopted the diametral tensile strength test ${ }^{3}$. In this test, a compressive force is applied to a cylindrical specimen across the diameter by compression plates. While the stresses in the contact regions are indeterminate, there is evidence of a compressive component that hinders the propagation of the tensile crack ${ }^{7}$. Large shear stresses that exist locally under the contact area may also induce a shear failure before tensile failure at the center of the specimen ${ }^{6,7}$.

For all cements, CS values were much higher than DTS values. Compressive strength was about 8-13 times greater than DTS. This may be explained because cohesion between the materials is identical in both compressive and diametral tensile strength tests, but the direction of forces is reversed ${ }^{24}$.

The results observed in this study were comparable to those presented in the literature concerning the Fuji IX DTS and CS values $^{19,23}$, probably due to standardization of procedures, especially those involved with measuring powder/liquid and manipulation according to manufacturers' instructions. This observation is of great importance to validate the present results and observations. There are studies with lower DTS values for Fuji IX, for example Iazzetti et $\mathrm{al}^{13}$, in 2001. This happens due to different variables, as operators and measuring and manipulating the material. It is not possible to perform a statistical analysis between these two studies to check if the lower values are significantly different, but assumptions can be made and the lower values can be attributed to different variants of the study.

In this study, Bioglass R and Vitro Molar showed an increased in CS between 1 hour and 7 days and between 1 hour and 24 hours, but no significant difference in strength was observed between 24 hours and 7 days. This increase in CS can be analyzed by the setting reaction of GICs. The calcium polycarboxylate is formed in the first 5-7 minutes after mixing. The aluminum polycarboxylate, which is more stable and improves the mechanical properties of the cement, takes 24 hours to be formed in the average. The setting reaction continues for at least 24 hours and probably much longer ${ }^{18,21}$. In contrast, the Fuji IX did not show statistically significant differences when CS was evaluated (1 hour, 24 hours and 7 days). This may be explained by the faster setting reaction of the high viscosity GICs (Fuji IX). According to the manufacturer, the relatively higher viscosity is the result of the addition of poly (acrylic acid) to the powder and finer grain-size distribution ${ }^{8,11}$ improved the mechanical properties of these cements mainly in the first hours ${ }^{11}$. No significant difference in strengths was observed between Fuji IX and Vitro Molar at 24hour and 7-day periods.

In relation to the DTS, also theoretically Fuji IX should be stronger at all time intervals, as the maturation of the cement takes place at a faster rate. The use of smaller particles to increase the setting reaction may, however, have a compromising effect on strength. The smaller irregularly shaped particles used could increase the risk for local stress concentrations and as a result of that facilitate local crack growth and decrease strength. This may be attributed to no significant differences observed in DTS among the three GICs tested at 1 hour.

TABLE 2- Mean Compressive Strength (CS) of GIC's in MPa and standard deviations (SD)

\begin{tabular}{llll}
\hline Glass-lonomer Cements & 1 hour & 24 hours & 7 days \\
\hline Bioglass R & $42.03(6.83)^{\mathrm{A} 1}$ & $83.39(16.60)^{\mathrm{A} 2}$ & $95.67(15.27)^{\mathrm{A} 2}$ \\
Vitro Molar & $70.26(6.05)^{\mathrm{B} 1}$ & $125.67(6.95)^{\mathrm{B} 2}$ & $148.03(17.80)^{\mathrm{B} 2}$ \\
Fuji IX & $99.51(7.91)^{\mathrm{C} 1}$ & $147.93(18.18)^{\mathrm{B} 2}$ & $155.47(9.02)^{\mathrm{B} 2}$ \\
\hline
\end{tabular}

Results designated with the same superscript characters are not statistically different $(p<0.05)$.

Letters are for comparisons between GIC's; numbers are for comparisons between times of the same material

TABLE 3- Mean Diametral Tensile Strength (DTS) of GIC's in MPa and standard deviations (SD)

\begin{tabular}{llll}
\hline Glass-Ionomer Cements & 1 hour & 24 hours & 7 days \\
\hline Bioglass R & $5.54(0.529)^{\mathrm{A} 1}$ & $6.58(0.808)^{\mathrm{B}}$ & $8.74(1.396)^{\mathrm{D} 1,2,3}$ \\
Vitro Molar & $8.27(0.475)^{\mathrm{A} 2}$ & $9.43(0.822)^{\mathrm{B}, \mathrm{C} 2}$ & $10.76(3.072)^{\mathrm{D}, \mathrm{E} 2,4}$ \\
Fuji IX & $7.24(0.699)^{\mathrm{A} \mathrm{3}}$ & $11.96(1.514)^{\mathrm{C} 4}$ & $13.72(2.834)^{\mathrm{E} 4}$ \\
\hline
\end{tabular}

Results designated with the same superscript characters are not statistically different $(p<0.05)$.

Letters are for comparisons between GIC's; numbers are for comparisons between times of the same material 
At 24-hour and 7-day periods, Bioglass R presented statistically significant lower DTS than Fuji IX, but Vitro Molar presented no statistical difference when compared to Bioglass R and Fuji IX. This may be explained in part by the low cohesive condition $^{20}$. The DTS measures the cohesive strength of the material, and the most brittle the material, the faster will be the occurrence of fracture. The cohesive properties of the material will influence the load necessary to produce fracture, independently of the deformation values.

The CS of amalgam is in the range of 300-450MPa, while that for composite resin is between $210-340 \mathrm{MPa}^{6}$. In addition, the DTS of amalgam and composite resin has been reported to be between $43-58 \mathrm{MPa}$ and $40-70 \mathrm{MPa}$ respectively ${ }^{6}$. In this study, the mean CS and DTS at 24 hours of the GICs tested, was still lower than that of the amalgam and composite resin, between 83.39-147.93MPa and 6.58-11.96MPa, respectively. It must be reiterated that, of the GICs tested, only Bioglass R showed a CS below the minimum strength at 24-hours periods of 125MPa required by British Standards ${ }^{3}$. The mean CS of Bioglass R at 1 hour, 24 hours and 7 days was very low, namely 42.03 - 83.39-95.67MPa, respectively.

\section{CONCLUSIONS}

The CS and DTS tests showed no significant difference between Fuji IX and Vitro Molar, except for CS test at 1-hour period. Bioglass R had lowest mean value for CS of the cements tested. In DTS test Bioglass R presented no statistically significant difference when compared to all others tested GICs at 1-hour period and Bioglass R presented no difference at 24hour and 7-day periods when compared to Vitro-Molar. Further studies to investigate other physical properties such as fracture toughness and wear resistance as well as chemical composition and biocompatibility are now needed to better understand the properties of these new Brazilian GICs.

\section{ACKNOWLEDGEMENT}

This study was partially supported by CAPES (Coordenação deAperfeiçoamento de Pessoal de Nível Superior). The authors would like to thank the manufacturers (Biodinamica, DFL, GC Corporation) for their generous supply of dental materials.

\section{REFERENCES}

1- American Dental Association, Specification n 66 for dental glass ionomer cements. Council on Dental Materials, Instruments and Equipment. J Am Dent Assoc 1989;119:205.

2- Anusavice KJ. Does ART have a place in preservative dentistry? Community Dent Oral Epidemiol 1999;27: 442-8.

3- British Standards Institution, British Standards Specification for Dental Glass Ionomer Cement BS 6039, 1981:4

4- Cattani-Lorente MA, Godin C, Meyer JM. Mechanical behavior of glass ionomer cements affected by long-term storage in water. Dent Mater 1994;10:37-44.
5- Cefaly DFG, Franco EB, Mondelli RFL, Francisconi PAS, Navarro MFL. Diametral tensile strength and water sorption of glass-ionomer cements used in Atraumatic Restorative Treatment. J Appl Oral Sci 2003;11:96-101.

6- Craig RG. Mechanical properties. In: materials. 10th. St. Louis:Mosby; c1997. p. 56-103.

Restorative dental

7- Darvell BW. Mechanical testing. In: Materials Science for Dentistry. 6th ed. Hong Kong : University of Hong Kong;2000. p.118.34 .

8- Frankenberger R.; Sindel J.; Kramer N. Viscous glass-ionomer cements: a new alternative to amalgam in the primary dentition? Quintessence Int 1997; 28: 667-76.

9- Frencken JE, Holmgren CJ. How effective is ART in the management of dental caries? Community Dent Oral Epidemiol 1999; 27(6): 42330 .

10- Gladys S, Van Meerbeek B, Braem M, Lambrechts P, Vanherle G. Comparative physico-mechanical characterization of new hybrid restorative materials with conventional glass-ionomer and resin composite restorative materials. J Dent Res 1997;76:883-94.

11- Guggenberger R, May R, Stefan KP. New trends in glass-ionomer chemistry. Biomaterials 1998;19: 479-83.

12- Horowitz AM. Introduction to the symposium on minimal intervention techniques for caries. J Public Hlth Dent 1996; 56(sp. Issue):133-4.

13- Iazzetti G, Burgess JO, Gardiner D. Selected mechanical properties of fluoride-releasing restorative materials. Oper Dent 2001;26:21-6.

14- Kerby RE, Knobloch L. Strenght characteristics of glass-ionomer cements. Oper Dent 1992; 17:170-4.

15- McKinney JE, Antonucci JM, Rupp NW. Wear and microhardness of glass-ionomer cements. J. Dent. Res. 1987;66:1134-39.

16- McLean JW. Glass-ionomer cement. Br Dent J 1988;164:293-300.

17- Naasan MA; Watson TF. Conventional glass ionomers as posterior restorations. A status report for the American Journal of Dentistry. Am J Dent 1998;11:36-45.

18- Pearson GJ, Atkinson AS. Long-term flexural strength of glass ionomer cements. Biomaterials 1991;12:658-60.

19- Pereira LC, Nunes MC, Dibb RG, Powers JM, Roulet JF, Navarro MF. Mechanical properties and bond strength of glass-ionomer cements. J Adhes Dent 2002;4:73-80.

20- Wang L, D’Alpino PHP, Lopes GL, Pereira JC. Mechanical properties of dental restorative materials: relative contribution of laboratory tests. J Appl Oral Sci 2003;11:162-7.

21- Williams JA, Billington RW. Changes in compressive strength of glass ionomer restorative materials with respect to time periods of $24 \mathrm{~h}$ to 4 months. J Oral Rehabil 1991;18:163-8.

22- Wilson $\mathrm{AD}$, Kent BE. The glass ionomer cement. A new translucent cement for dentistry. J Appl Chem Biotechnol 1971;21:313.

23- Xie D, Brantley WA, Culbertson BM, Wang G. Mechanical properties and microstructures of glass-ionomer cements. Dent Mater 2000;16:12938 .

24- Yap AUJ, Pek YS, Cheang P. Physico-mechanical properties of a fast-set highly viscous GIC restorative. J Oral Rehabil 2003;30:1-8. 